\title{
Analysis and Evaluation on Characteristics of Heavy Metal Pollution in the Coastal Farmland Soil along the Wuma River
}

\author{
Xiongfei Cai*, Die Xu*, Shijie Zhao*, Li Lei*, Ji Wang*† and Bin Xuan* \\ *School of Geographic and Environmental Sciences, Guizhou Normal University, Guiyang, 550025, China \\ †Corresponding author: Ji Wang; $1907154961 @$ qq.com
}

Nat. Env. \& Poll. Tech.

Website: www.neptjournal.com

Received: 17-11-2020

Revised: $12-01-2021$

Accepted: 22-01-2021

Key Words:

Wuma river

Coastal farmland

Soil

Heavy metal

\section{ABSTRACT}

The thesis is aimed to provide a reference for the sustainable utilization of farmland soils along the Wuma River, an upstream tributary of the Chishui River in Guizhou Province. Geo accumulation index method, Nemero comprehensive pollution index method, and potential ecological hazard index method were used based on the experimental data for analyzing and evaluating the heavy metal pollution status of farmland soil along Wuma River. The results showed that: (1) The contents of heavy metals $\mathrm{Ni}, \mathrm{Cu}, \mathrm{Zn}, \mathrm{Pb}$ and $\mathrm{Hg}$ in farmland soil exceeded the soil background values of $9.82 \%, 47.80 \%, 13.72 \%$ and $76.06 \%$ in Guizhou Province, respectively, but did not exceed the standard limit class II based on the environmental quality. (2). The pollutants of $\mathrm{Pb}$ and $\mathrm{Zn}$ in the research area mainly come from mineral exploitation, waste residue accumulation, and transportation. The enrichment of $\mathrm{Cr}$ and $\mathrm{Cu}$ may originate from the domestic garbage dumping and incinerated waste by residents along the coast and irrational agricultural activities. The main contents of $\mathrm{Cd}$, As and $\mathrm{Hg}$ come from soil geochemistry. (3) The ranking of accumulations of eight heavy metals was $I_{\mathrm{Pb}}>I_{\mathrm{Hg}}>I_{\mathrm{Cu}}>I_{\mathrm{Ni}}>I_{\mathrm{Zn}}>I_{\mathrm{Cr}}>I_{\mathrm{As}}>I_{\mathrm{Cd}}$, among which $\mathrm{Pb}$ was non-moderately polluted and the remaining heavy metals were at the clean level; Nemero comprehensive pollution index showed that $\mathrm{As}, \mathrm{Cr}, \mathrm{Zn}$, and $\mathrm{Ni}$ were mildly polluted, while $\mathrm{Pb}, \mathrm{Hg}$, and $\mathrm{Cu}$ were moderately polluted. The ranking of potential ecological risk levels for the eight heavy metals was $\mathrm{Hg}, \mathrm{Pb}, \mathrm{Cu}, \mathrm{Ni}, \mathrm{As}, \mathrm{Cd}, \mathrm{Cr}, \mathrm{Zn}$. The overall ecological risk level is mild.

\section{INTRODUCTION}

At present, farmland soils in China are threatened by various kinds of pollution, among which about 50 million mu farmland is moderately and severely polluted with $80 \%$ of the soil pollution by excessive contents of heavy metals (Wang et al. 2014, Chen et al. 2016). Heavy metal elements have unique environmental toxicological effects, so they cannot be degraded by microorganisms after entering farmland soil, and gradually accumulate in soil environment and organisms. They not only do harm to the quality and yield of crops but also cause potential harm to human health through the food chain (Massadeh et al. 2006, Zeng et al. 2010). In recent years, domestic and foreign scholars have investigated farmland soil in the basin many times. Marrugo-Negrete et al. (2017) surveyed 83 farmland soil samples from Sinú River in northern Colombia. The results showed that the average contents of $\mathrm{Cu}, \mathrm{Ni}, \mathrm{Hg}$, and $\mathrm{Zn}$ were $1,149,661,0.159$, and $1,365 \mathrm{mg} \cdot \mathrm{kg}-1$, respectively, which exceeded the background values of soil in the same area. Influenced by the coastal industrial zone, $\mathrm{Ni}, \mathrm{Cu}$, and $\mathrm{Zn}$ were moderate to heavily polluted (Perveen et al. 2017). Based on the comparison and analysis of the contents of heavy metals in farmland soils along the upper and lower reaches of Swan River, an industrial area adjacent to Islamabad, Pakistan, it was found that the concentrations of $\mathrm{Cr}, \mathrm{Ni}, \mathrm{Cd}, \mathrm{Zn}, \mathrm{Pb}$ and $\mathrm{Cu}$ in the downstream were $149 \%, 131 \%, 176 \%, 139 \%, 224 \%$ and $182 \%$ of those in the upstream. Zhou et al. (2008) and Jin et al. (2017) investigated heavy metals in farmland along the Bijiang River in Yunnan Province and found that the concentrations of $\mathrm{Pb}, \mathrm{Cd}$, and $\mathrm{Zn}$ content could be regarded as serious pollution. Guo et al. (2017) evaluated the distribution characteristics and potential ecological risks of heavy metals in farmland soils along Xinqianghe River in a typical leadzinc mining area. The results showed that there were many heavy metals in the coastal farmland where Cd dominated, with the existence of $\mathrm{As}, \mathrm{Cu}, \mathrm{Ni}, \mathrm{Pb}$, and $\mathrm{Zn}$. Wu et al. (2011) investigated the contamination status of seven heavy metals in the surface soil of farmland around Puhe River, Hunhe River, Xihe River, and Shenfu Irrigation Canal in Shenyang. According to their investigation, $\mathrm{Cd}, \mathrm{Hg}$, and $\mathrm{Zn}$ pollution were found to be more common in these river areas.

It is thus clear that the pollution of heavy metals in river basins is becoming more severe. Therefore, researchers pay great attention to the environmental and ecological security of river basins in the current environment. However, there are few reports on the pollution of heavy metals in farmland 
in the upper reaches of Chishui River, Guizhou Province. Therefore, it is particularly important to investigate and evaluate the present heavy metals pollution in farmland soil in Chishui River Basin. This thesis conducted a study on the soil along the Wuma River, a tributary of the upper reaches of the Chishui River. The pollution status of 8 heavy metals, such as $\mathrm{Ni}, \mathrm{Cr}, \mathrm{Cu}, \mathrm{Zn}, \mathrm{Pb}, \mathrm{Cd}$, As, and $\mathrm{Hg}$, was analyzed based on the field investigation and experimental analysis through the methods of the geo-accumulation index and Nemerow comprehensive pollution index. In addition, the potential ecological risk index method was used to assess the ecological risk of farmland soil in the basin. All the above methods were used to provide a reference for the sustainable use of farmland soil and the maintenance of sound farmland ecosystem in the basin.

\section{MATERIALS AND METHODS}

\section{Survey on Research Areas}

The Wuma River is an important tributary of the Chishui River in Renhuai, is part of the Yangtze River system. The Wuma River Basin is located in the southwest of Renhuai City $\left(106.1-106.6^{\circ} \mathrm{E}, 27.5-27.8^{\circ} \mathrm{N}\right)$, and the boundary area between Guizhou and Sichuan provinces. It mainly consists of four townships, including Changgang, Luban, Wuma, and Maoba under the jurisdiction of Renhuai City, Guizhou Province. The total length of it is $39.3 \mathrm{~km}$ and an average annual discharge, $4.98 \mathrm{~m}^{3} \cdot \mathrm{s}^{-1}$. The climate in the research area is the humid monsoon climate in the middle subtropical zone, with distinct seasons. The rain season and hot season are basically the same, the annual average temperature is 15.9-18.5, and the annual average precipitation is $1,081 \mathrm{~mm}$. Main soil types can be divided into lime soil, yellow soil, purple soil, paddy soil, and yellow-brown soil. The main produced crops include rice, rape, maize, wheat, sorghum, and tobacco.

\section{Sample Collection}

From April to May 2017, a survey was carried out on the Wuma River Basin. According to the distribution of farmland in the basin, one sampling point was set every $1 \mathrm{~km}$ along the basin, and the location information was recorded by GPS positioning within $1 \mathrm{~km}$ from the riverbank. In the sampling process, based on the Technical Specification for Monitoring the Environmental Quality of Farmland Soil (NY/T 395-2000), five sub-sampling points were set up in the form of "plum blossom" or "serpentine" within the grid of $10 \mathrm{~m} * 10 \mathrm{~m}$. The surface soil from $0-20 \mathrm{~cm}$ was collected, and then mixed samples were formed. The soil samples were selected repeatedly by the four-point method and only about $1 \mathrm{~kg}$ was preserved. A total of 63 soil samples were collected. After air drying, grinding, and sifting (100 meshes), the soil was selected for determination and analysis (Bao 2007). The distribution of sampling points in the research area is shown in Fig. 1.

\section{Sample Processing and Analysis}

After using the tetra acid melting sample method (aqua regia, $\mathrm{HClO} 4, \mathrm{HF}$ ) on an electrothermal plate at 140 for continuous heating and digestion, Copper $(\mathrm{Cu})$, cadmium $(\mathrm{Cd})$, lead $(\mathrm{Pb})$, zinc $(\mathrm{Zn})$, nickel $(\mathrm{Ni})$ and chromium $(\mathrm{Cr})$ were determined

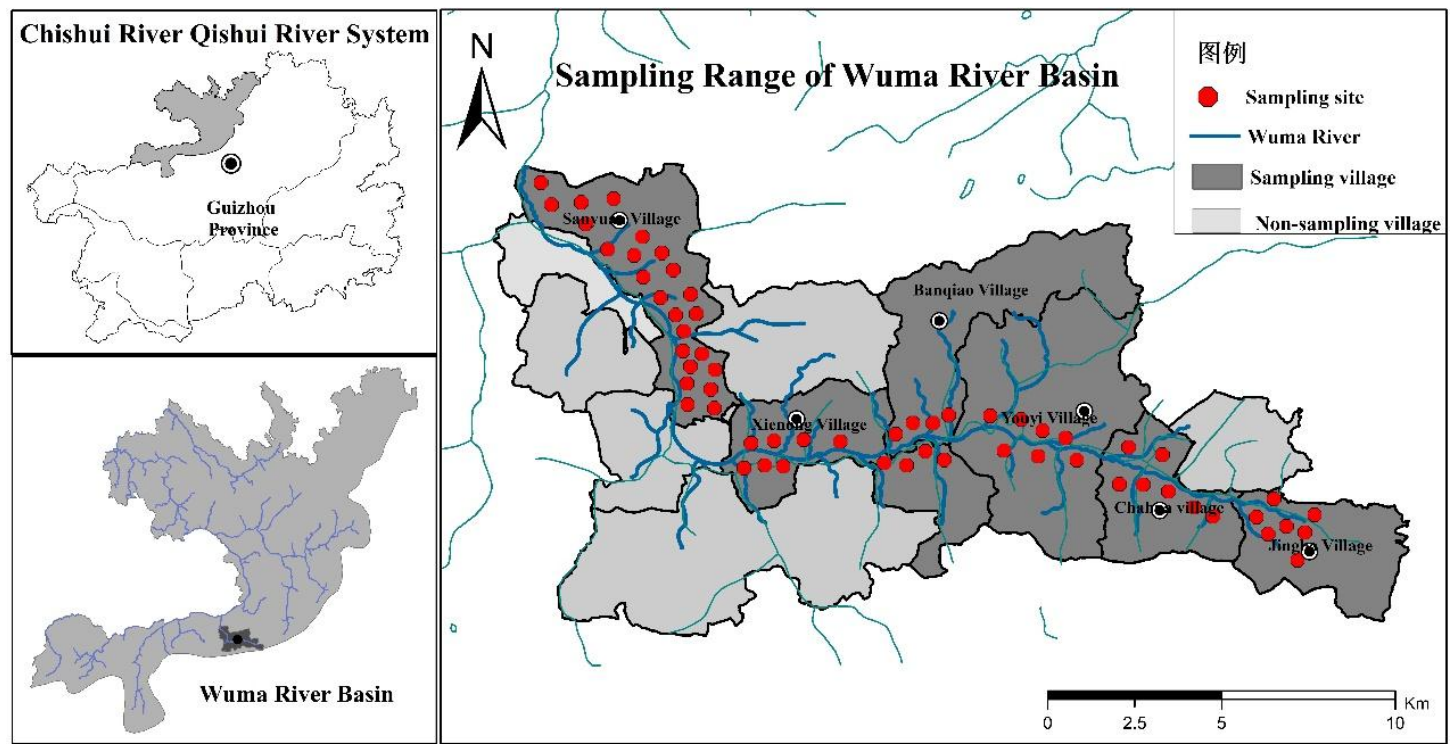

Fig. 1: Location of the research area and sampling sites. 
by flame atomic absorption spectrometry (AAS-G800). Mercury ( $\mathrm{Hg}$ ) and arsenic (As) were digested by the aqua regia heating method and determined by atomic fluorescence spectrometry (AFS-E230). For the accuracy of the analysis, the national standard substance (GBW07309) was used for controlling the quality in the experimental process, and the parallel sample analysis was carried out. The test error was controlled within $5 \%$.

\section{Evaluation Methodology}

Taking the background value of soil layer A in Guizhou Province as the evaluation criterion. The Muller cumulative index method $\left(I_{g e o}\right)$ and Nemero comprehensive pollution index method were used for evaluating the farmland soil pollution in the research area. Based on the Grade II standard $(\mathrm{pH}>$ 7.5) of the National Soil Environmental Quality Standard (GB15618-1995), the potential ecological risk index (RI) method proposed by Hakanson (1980) was used to assess the potential ecological risk. The toxicity response parameters of heavy metals $T_{r}^{i}$ were adopted based on the reference values proposed by Hakansao (1980) (toxicity response coefficients of $T_{r}^{i}$ to heavy metals $\mathrm{As}=10, \mathrm{Zn}=\mathrm{Mn}=1, \mathrm{Cu}=\mathrm{Pb}=5, \mathrm{Cr}=$ $2, \mathrm{Cd}=30, \mathrm{Hg}=40)(\mathrm{Li}$ et al. 2015). The specific evaluation methods are shown in Table 1.

The pollution level $I_{\text {geo }}$ is graded as follows: $I_{\text {geo }} \leq 0$ means pollution-free; $0<I_{g e o} \leq 1$ means pollution-free-to-moderate pollution; $1<I_{\text {geo }} \leq 2$ refers to moderate pollution; $2<I_{\text {geo }} \leq 3$ means medium-to-heavy pollution; $3<I_{\text {geo }} \leq 4$ means heavy pollution; $4<I_{g e o} \leq 5$ means heavy-to-seriously heavy pollution; and $I_{g e o}>5$ means seriously heavy pollution. Nemerow's comprehensive pollution index is graded as follows: $\mathrm{P} \leq 0.7$ means clean; $0.7<\mathrm{P} \leq 1.0$ means reaching the warning line; $1.0<\mathrm{P} \leq 2.0$ means slight pollution; $2.0<\mathrm{P} \leq 3.0$ means moderate pollution; $\mathrm{P}>3.0$ means heavy pollution. The degree of single-factor ecological risk pollution $E_{r}^{i}$ is divided into the following grades: $E_{r}^{i}<40$ means mild pollution; $40 \leq E_{r}^{i}$
$<80$ means moderate pollution; $80 \leq E_{r}^{i}<160$ means heavy pollution; $160 \leq \mathrm{E}_{\mathrm{r}}^{\mathrm{i}}<320$ means very heavy pollution; and $\mathrm{E}_{\mathrm{r}}^{\mathrm{i}}$ $\geq 320$ means seriously heavy pollution. The total potential ecological risk level $\mathrm{R}$ is graded as follows: $\mathrm{R}<150$ is mild; $150 \leq \mathrm{R}<300$ means moderate; $300 \leq \mathrm{R}<600$ means strong; $\mathrm{R} \geq 600$ refers to very strong.

\section{RESULTS AND DISCUSSION}

Analysis of heavy metals in soil, according to Table 1, show that the upper limits and bottom limits for contents of $\mathrm{Ni}, \mathrm{Cr}$, $\mathrm{Cu}, \mathrm{Zn}, \mathrm{Pb}, \mathrm{Cd}, \mathrm{As}$, and $\mathrm{Hg}$ in farmland soil along the Wuma River Basin varied greatly, ranging from 11.02 to 70.95 , 14.57 to $135.20,9.24$ to $80.20,42.58$ to $182.26,18.34$ to $87.13,0.003$ to $0.076,3.18$ to $18.91,0.074$ to $0.307 \mathrm{mg} \cdot \mathrm{kg}^{-1}$, respectively. The average contents of heavy metals $\mathrm{Ni}, \mathrm{Cr}$, $\mathrm{Cu}, \mathrm{Zn}, \mathrm{Pb}, \mathrm{Cd}, \mathrm{As}$, and $\mathrm{Hg}$ were 37.01, 64.55, 37.98, 93.70, $51.58,0.013,6.32$, and $0.148 \mathrm{mg} \cdot \mathrm{kg}^{-1}$, respectively. The average contents of $\mathrm{Ni}, \mathrm{Cu}, \mathrm{Zn}, \mathrm{Pb}$, and $\mathrm{Hg}$ exceeded the Guizhou Province's background values of 9.82\%, 47.80\%, 13.72\%, and $76.06 \%$, respectively. However, the average contents of all heavy metals did not exceed the grade II standard limit according to the national soil environmental quality.

Skewness is statistical data for the shape of data distribution, and kurtosis is statistical data for showing the steepness of all values in the population (Zhan et al. 2011). Based on the heavy metals statistical results of the research area, skewness and kurtosis coefficients of $\mathrm{Zn}, \mathrm{Cd}, \mathrm{As}$, and $\mathrm{Hg}$ were larger, indicating that some soil samples presented high content and were highly accumulated. The coefficient of variation can reflect the average variation degree of heavy metal content in different sites. According to the classification of variation degree by Wilding (1984), Ni, Cd, Zn and Hg (coefficients of variations were $35 \%, 32 \%, 32 \%$, and $28 \%$, respectively) were moderate (ranged from $15 \%$ to $36 \%$ ), while $\mathrm{Cu}, \mathrm{Pb}$, $\mathrm{Cd}$ and As (coefficients of variation were $40 \%, 38 \%, 72 \%$, and $41 \%$, respectively) were highly variable (Zang et al.

Table 1: The assessment of geo-accumulation index, Nemerow comprehensive polluted index, and potential ecological risk index for heavy metals.

\begin{tabular}{|c|c|c|}
\hline Index & Expression & Parameter \\
\hline $\begin{array}{l}\text { Geo-accumulation } \\
\text { index }\end{array}$ & $I_{g e o}=\log _{2}\left[C_{n} /\left(k \times B_{n}\right)\right]$ & $\begin{array}{l}C_{n}=\text { Content of heavy metal element } \mathrm{n} \text { in the soil; } \\
B_{n}=\text { Geochemical background value of heavy metal element } \mathrm{n} \text {; } \\
\mathrm{K}=\text { Coefficient of variation of background values caused by different rocks. }\end{array}$ \\
\hline $\begin{array}{l}\text { Nemerow compre- } \\
\text { hensive polluted } \\
\text { index }\end{array}$ & $P_{\text {综合 }}=\sqrt{\frac{\left(C_{i} / S_{i}\right)_{\max }^{2}+\left(C_{i} / S_{i}\right)_{a v e}^{2}}{2}}$ & $\begin{array}{l}C_{i}=\text { Concentration of soil pollutant } \mathrm{i} \text {; } \\
S_{i}=\text { Background concentration of soil pollutant } \mathrm{i} \text {; } \\
\left(C_{i} / S_{i}\right)_{\max }=\text { The maximum of single factor pollution index for soil pollutant } \mathrm{i} \text {; } \\
\left(C_{i} / S_{i}\right)_{\text {ave }}=\text { Average value of single factor pollution index for soil pollutant } \mathrm{i} \text {. }\end{array}$ \\
\hline $\begin{array}{l}\text { Potential ecologi- } \\
\text { cal risk index }\end{array}$ & $R I=\sum E_{r}^{i}=\sum\left(T_{r}^{i} \cdot C_{r}^{i}\right)=\sum\left(T_{r}^{i} \cdot \frac{C_{m}^{i}}{C_{n}^{i}}\right)$ & $\begin{array}{l}\mathrm{R}=\text { Comprehensive potential ecological hazard index of several heavy metals; } \\
E_{r}^{i}=\text { Potential ecological hazard coefficient of a single heavy metal; } \\
T_{r}^{i}=\text { Toxicity response coefficient for heavy metals; } \\
C_{r}^{i}=\text { Pollution coefficient of this element; } \\
C_{n}^{i}=\text { Evaluation criterion of this element. }\end{array}$ \\
\hline
\end{tabular}


2016). If the coefficient of variation exceeds 0.5 , the spatial distribution of heavy metal content is not uniform, and the point source pollution may exist (Aguiguri et al. 2017). The coefficient of variation of heavy metal $\mathrm{Cd}$ in the soil of the research area was 0.72 . It can be seen that the variation of heavy metal $\mathrm{Cd}$ was significant, indicating that $\mathrm{Cd}$ was more prone to be affected by some local pollution sources. The average value of soil $\mathrm{pH}$ value was 7.93 and was of weak alkalinity. The skewness, kurtosis, and coefficient of variation were $-1.20,0.55$, and 0.12 , respectively. Therefore, the distribution of soil $\mathrm{pH}$ value was uniform and no obvious acid-base anomaly was observed.

\section{Relevance and Source Analysis of Heavy Metals in Soil}

The heavy metals in soils come from not only the parent soil layer but also agricultural activities (including irrigation water, agriculture, fertilizer), atmospheric dust, and industrial pollution (Zhang et al. 2012). The correlation coefficients between heavy metals are indicators for the relationship among different pollution sources. Generally, heavy metals with higher correlation coefficients are dependent on each other and may have similar sources. Heavy metals with a low correlation coefficient have weak dependence and different sources (Hu 2014). The results from correlation analysis (Table 3 ) proved that there was a significant positive correlation between $\mathrm{Cd}$ and $\mathrm{Hg}$ and between $\mathrm{As}$ and $\mathrm{Ni}(\mathrm{P}<0.01)$, an obvious positive correlation between $\mathrm{Zn}$ and $\mathrm{Cu}, \mathrm{Pb}, \mathrm{Cd}$, and As $(\mathrm{P}<0.05)$, and a significant positive correlation between $\mathrm{As}, \mathrm{Cu}$, and $\mathrm{Hg}(\mathrm{P}<0.05)$ in farmland soil along the Wuma River. The above correlations between different elements indicate that the enrichment of these elements might come from similar sources.

Table 2: Statistic of heavy metal concentrations in the research area $(n=63)$.

\begin{tabular}{|c|c|c|c|c|c|c|c|c|c|}
\hline $\begin{array}{l}\text { Ele- } \\
\text { ments }\end{array}$ & $\begin{array}{l}\text { Max. } \\
\left(\mathrm{mg} \cdot \mathrm{kg}^{-1}\right)\end{array}$ & $\begin{array}{l}\text { Min. } \\
\left(\mathrm{mg} \cdot \mathrm{kg}^{-1}\right)\end{array}$ & $\begin{array}{l}\text { Avg. } \\
\left(\mathrm{mg} \cdot \mathrm{kg}^{-1}\right)\end{array}$ & 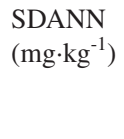 & $\begin{array}{l}\text { Skew- } \\
\text { ness }\end{array}$ & Kurtosis & $\begin{array}{l}\text { Coeffi- } \\
\text { cient of } \\
\text { variation }\end{array}$ & $\begin{array}{l}\text { Background } \\
\text { value }\left(\mathrm{mg} \cdot \mathrm{kg}^{-1}\right)\end{array}$ & $\begin{array}{l}\text { National } \\
\text { standard } \\
\left(\mathrm{mg} \cdot \mathrm{kg}^{-1}\right)\end{array}$ \\
\hline $\mathrm{Ni}$ & 70.95 & 11.02 & 37.01 & 12.99 & 0.18 & -0.55 & 0.35 & 33.7 & 40 \\
\hline $\mathrm{Cr}$ & 135.20 & 14.57 & 64.55 & 20.70 & 0.85 & 2.02 & 0.32 & 86.6 & 250 \\
\hline $\mathrm{Cu}$ & 80.20 & 9.24 & 37.98 & 15.18 & 0.28 & 0.01 & 0.40 & 25.7 & 50 \\
\hline $\mathrm{Zn}$ & 182.26 & 42.58 & 93.70 & 30.19 & 1.16 & 1.16 & 0.32 & 82.4 & 200 \\
\hline $\mathrm{Pb}$ & 87.13 & 18.34 & 51.58 & 19.42 & 0.04 & -1.21 & 0.38 & 29.3 & 250 \\
\hline $\mathrm{Cd}$ & 0.076 & 0.003 & 0.013 & 0.01 & 5.06 & 33.75 & 0.72 & 0.133 & 1 \\
\hline As & 18.91 & 3.18 & 6.32 & 2.59 & 2.70 & 10.20 & 0.41 & 13.3 & 20 \\
\hline $\mathrm{Hg}$ & 0.307 & 0.074 & 0.148 & 0.04 & 1.75 & 5.14 & 0.28 & 0.102 & 1 \\
\hline $\mathrm{pH}$ & 8.95 & 5.23 & 7.93 & 0.94 & -1.20 & 0.55 & 0.12 & - & - \\
\hline
\end{tabular}

Notes: 1) Background value of farmland soil in Guizhou; 2) Grade II Standard according to the National Soil Environmental Quality Standard (GB15618-1995) $(\mathrm{pH}>7.5)$

Table 3: Correlation coefficients of metals in soil.

\begin{tabular}{|llllllll}
\hline & $\mathrm{Ni}$ & $\mathrm{Cr}$ & $\mathrm{Cu}$ & $\mathrm{Zn}$ & $\mathrm{Pb}$ & $\mathrm{Cd}$ & $\mathrm{As}$ \\
$\mathrm{Ni}$ & 1 & & & & & \\
$\mathrm{Cr}$ & 0.077 & 1 & & & & \\
$\mathrm{Cu}$ & 0.138 & 0.112 & 1 & & & \\
$\mathrm{Zn}$ & -0.089 & 0.018 & $0.251^{*}$ & 1 & & & \\
$\mathrm{~Pb}$ & -0.202 & 0.017 & -0.133 & $0.262^{*}$ & 1 & & \\
$\mathrm{Cd}$ & $0.332^{* *}$ & 0.109 & 0.17 & $0.256^{*}$ & -0.051 & 1 & 1 \\
$\mathrm{As}$ & 0.234 & 0.13 & $0.278^{*}$ & $0.253^{*}$ & -0.148 & $0.559^{* *}$ & 1 \\
$\mathrm{Hg}$ & 0.198 & 0.059 & 0.13 & $0.233^{*}$ & -0.151 & $0.504^{* *}$ & $0.281^{*}$ \\
\hline
\end{tabular}

Notes: ** indicates a significant correlation at the 0.01 (bilateral) level, and * indicates a significant correlation at the 0.05 (bilateral) level. 
Based on results of principal component analysis on heavy metals in farmland along the Wuma River, the chisquare value of the Bartlett spherical test was 76.518, and the degree of freedom df was 32 (usually df 30 , so it had strong reliability). Therefore, the principal component analysis could be made. Table 4 shows that the variance contribution rate of principal component 1 is $29.924 \%$. The positive load coefficients of $\mathrm{Cd}$, As and $\mathrm{Hg}$ in principal component 1 are larger, and there is a significant correlation between $\mathrm{Cd}$ and $\mathrm{As}, \mathrm{Cd}$ and $\mathrm{Hg}(\mathrm{P}<0.01)$, indicating that $\mathrm{Cd}$, As and $\mathrm{Hg}$ may have similar sources. The variance contribution rate of principal component 2 is $17.165 \%$. The positive load coefficients of $\mathrm{Pb}$ and $\mathrm{Zn}$ are larger, and the correlation between $\mathrm{Pb}$ and $\mathrm{Zn}$ is 0.05 in terms of confidence level. The variance contribution rate of principal component 3 is $12.661 \%$. The larger positive loads of $\mathrm{Cr}$ and $\mathrm{Cu}$ show that the enrichment of the same principal component element comes from the same source.

According to the above statistical results (Table 2), the contents of $\mathrm{Cd}$, As and $\mathrm{Hg}$ are not significantly different from the background values of soil in Guizhou Province. Therefore, it can be inferred that principal component 1 may be a natural source. The reason is that affected by karst geological origin, the Wuma River Basin has higher geological background contents of $\mathrm{Cd}, \mathrm{As}$, and $\mathrm{Hg}$ than other elements (Lian 2010). They all originate from the parent material of soil formation and are controlled by soil geochemistry. The average contents of $\mathrm{Pb}$ and $\mathrm{Zn}$ exceed the background values of soil. The contents of $\mathrm{Cr}$ and $\mathrm{Cu}$ greatly exceed the standard in some places. Therefore, principal components 2 and

Table 4: Analysis result of principal components of heavy metals in soil.

\begin{tabular}{|llll|}
\hline Items & Principal component 1 & Principal component 2 & Principal component 3 \\
\hline $\mathrm{Ni}$ & 0.479 & -0.499 & -0.01 \\
$\mathrm{Cr}$ & 0.229 & 0.012 & 0.795 \\
$\mathrm{Cu}$ & 0.472 & 0.087 & 0.459 \\
$\mathrm{Zn}$ & 0.414 & 0.745 & -0.048 \\
$\mathrm{~Pb}$ & -0.215 & 0.748 & -0.015 \\
$\mathrm{Cd}$ & 0.816 & 0.039 & -0.218 \\
$\mathrm{As}$ & 0.754 & 0.022 & 0.036 \\
$\mathrm{Hg}$ & 0.661 & -0.001 & -0.343 \\
Eigen value & 2.394 & 1.373 & 1.013 \\
Variance concentration rate $(\%)$ & 29.924 & 17.165 & 12.661 \\
Cumulative variance contribution rate $(\%)$ & 29.924 & 47.089 & 59.750 \\
\hline
\end{tabular}

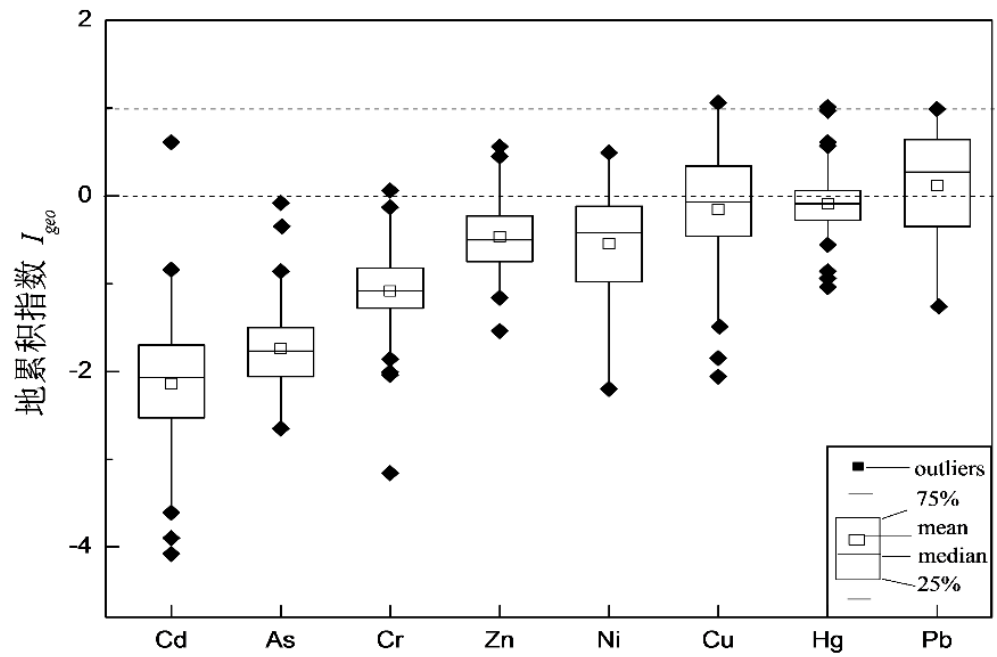

Fig. 2: The map of heavy metals of the index of geo-accumulation in the Wuma river. 
3 may be influenced by artificial sources. Coastal farmland mainly depends on the Wuma River for irrigation. However, in the coastal area of the Wuma River, there is Tonglong Coal Mine, Sanyuan Coal Mine, and small-scale $\mathrm{Pb}-\mathrm{Zn}$ Mine, etc. The waste residue produced in the process of mining and smelting combustion will bring about pollution in the rivers and coastal soil. In addition, due to the narrow landscape, No. 208 Provincial Road and No. 324 Village Road are close to the river coast. The wear and tear of vehicles and exhaust emissions will lead to the pollution of $\mathrm{Pb}$ and $\mathrm{Zn}$ in the farmland soil. Therefore, it is presumed that principal component 2 mainly comes from mineral mining and smelting, waste residue accumulation, irrigation, and transportation. Previous studies have shown that waste accumulation and incineration, transportation, and unreasonable agricultural activities may lead to the pollution of $\mathrm{Cr}$ and $\mathrm{Cu}$ (Zhao et al. 2015). Wuma Town in the middle and lower reaches of the Wuma River and the coastal villages in the upper reaches do not have a perfect waste treatment system. As residents along the river dump wasted pesticide bottles directly in the river or set them aside in the river bed for incineration, the river water and the surrounding environment are seriously polluted. At the same time, $\mathrm{Cr}$ and $\mathrm{Cu}$ have been accumulated in the farmland soil after river irrigation. Therefore, principal component 3 may be presumed to be mainly derived from the dumping and incineration of domestic waste by coastal residents, and unreasonable agricultural operations.

\section{Assessment on Heavy Metal Pollution in Farmland Soil}

The results of the geo-accumulation index $\left(I_{\text {geo }}\right)$ of 8 heavy metals in farmland soils of the Wuma River Basin are shown in Fig. 2. According to the average of $I_{\text {geo }}, 8$ heavy metals are ranked as follows: $\mathrm{I} \mathrm{Pb}>\mathrm{I} \mathrm{Hg}>\mathrm{I} \mathrm{Cu}>\mathrm{I} \mathrm{Ni}>\mathrm{I} \mathrm{Zn}>\mathrm{I} \mathrm{Cr}>\mathrm{I}$ As $>\mathrm{I} \mathrm{Cd}$. Except for $I_{\text {geo }}>0$ of $\mathrm{Pb}$ which had no-to-moderate pollution, the $I_{\text {geo }}$ of other heavy metals was less than 0 and in a clean level. Several locations of $\mathrm{Pb}, \mathrm{Hg}$, and $\mathrm{Cu} I_{g e o}>1$ had moderate pollution, indicating that there was point source pollution in farmland soil in the basin.

According to statistical results of the Nemero comprehensive pollution index of eight heavy metals in farmland soil of Wuma River Basin (Table 5), the $p$-value of Cd was under the warning level, indicating no pollution $(\mathrm{p}<1)$. Cr, $\mathrm{Zn}$, and $\mathrm{Ni}$ were slightly polluted $(1.0<\mathrm{p} \leq 2.0)$, while $\mathrm{Hg}$, $\mathrm{Cu}$, and $\mathrm{Pb}$ were moderately polluted $(2.0<\mathrm{p} \leq 3.0)$. Nemero comprehensive pollution index also takes into account the average and maximum values of single factor pollution index, so it can highlight the role of heavy metal pollutants (Wang et al. 2012). However, the evaluation results of the Nemero comprehensive pollution index basically conform to the cumulative evaluation results.

After calculation on $E_{r}^{i}$ for single potential ecological hazard index for heavy metals in farmland soil along the Wuma River (see Fig. 3), the average potential hazard index of eight heavy metals was ranked as $\mathrm{Hg}>\mathrm{Pb}>\mathrm{Cu}>\mathrm{Ni}>\mathrm{As}>\mathrm{Cd}$

Table 5: Nemero comprehensive polluted index of heavy metals in soil.

\begin{tabular}{|lllllllll|}
\hline Heavy metals & $\mathrm{Cd}$ & $\mathrm{As}$ & $\mathrm{Cr}$ & $\mathrm{Zn}$ & $\mathrm{Ni}$ & $\mathrm{Hg}$ & $\mathrm{Cu}$ & $\mathrm{Pb}$ \\
\hline Comprehensive polluted of P value & 0.41 & 1.06 & 1.22 & 1.76 & 1.68 & 2.36 & 2.43 & 2.44 \\
\hline
\end{tabular}

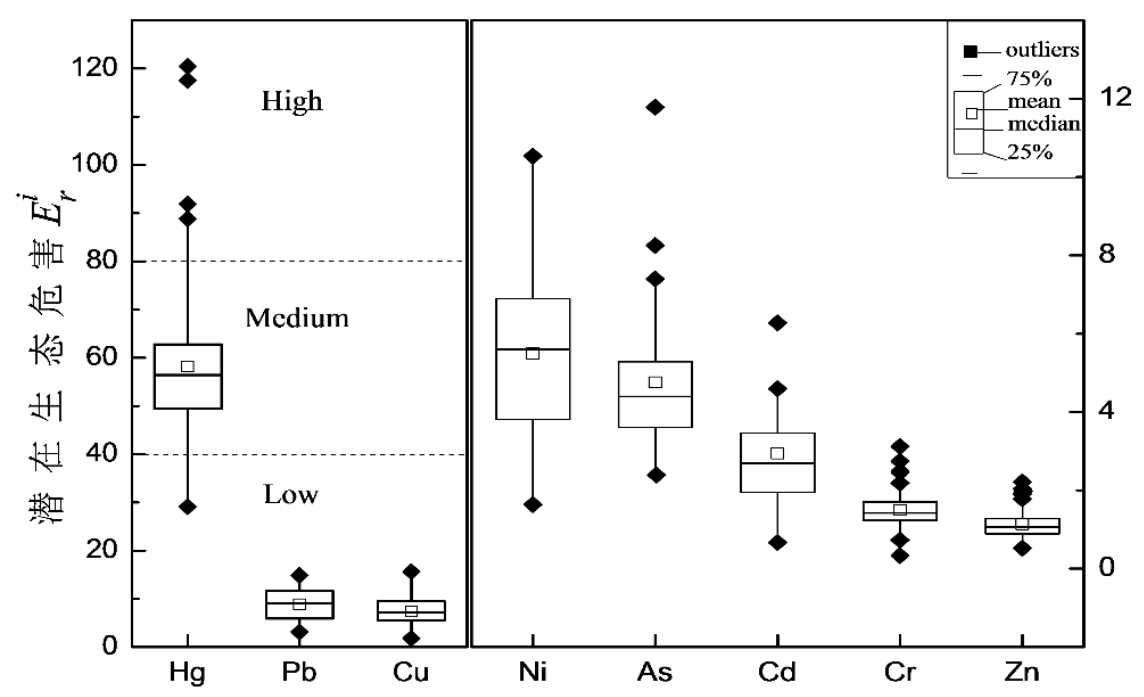

Fig. 3: The map of single potential ecological hazard indexes of heavy metals in soil. 
$>\mathrm{Cr}>\mathrm{Zn}$ from maximum to minimum amount. According to the risk level of ecological hazards, the average potential hazard index of $\mathrm{Hg}$ was more than 40 and was at moderate risk. The $E_{r}^{i}$ value of some sample points was between 80 and 160, indicating strong ecological hazards. The $E_{r}^{i}$ values of the other 7 heavy metals, $\mathrm{Pb}, \mathrm{Cu}, \mathrm{Ni}, \mathrm{As}, \mathrm{Cd}, \mathrm{Cr}$, and $\mathrm{Zn}$ were $8.80,7.39,5.49,4.76,2.94,1.49$, and 1.14 , respectively, so it can be seen that all the $E_{r}^{i}$ values were less than 40 , and at a slight potential hazard level. The comprehensive index $R I$ of potential ecological hazards of heavy metals in farmland soils in the research area ranged from 56.34 to 183.59 , with an average value of 90.21 , showing a slight potential ecological hazard as a whole.

After integration of 3 evaluation methods, it was concluded that the accumulative degree of $\mathrm{Pb}, \mathrm{Cu}$, and $\mathrm{Hg}$ in farmland soil and the comprehensive pollution index of Nemerow were higher in the research area. Although $\mathrm{Pb}$ and $\mathrm{Cu}$ were highly contaminated, the potential hazards caused by their toxicity were relatively low. $\mathrm{Hg}$ had a low pollution degree but relatively high potential toxicity. The pollution degree of $\mathrm{Cr}$ and $\mathrm{Zn}$ was higher than their potential toxicity.

Potential ecological hazard coefficients are slightly different from the results of the geo-accumulation index method. The reason is that the two evaluation methods have different focuses. The geo-accumulation index method mainly targets the influence of geochemical behavior, emphasizing the influence of exogenous sources on the enrichment of heavy metals through the anthropogenic and natural background values of heavy metals (Yu et al. 2013). In addition to the contents of heavy metals, the ecological hazard index also takes into account the varied environmental toxicity among different heavy metals, but it emphasizes more on the ecological risk of heavy metals and therefore can bring much healthier ecosystems. It is thus clear that the combination of various evaluation methods can provide a more comprehensive and reasonable understanding of heavy metal pollution and hazards in farmland soils in the research area.

\section{CONCLUSION}

Through the test, analysis, and evaluation on heavy metal pollution in farmland soil along the Wuma River, the following main conclusions are drawn:

1. In terms of the contents of heavy metals in farmland soil, the average contents of $\mathrm{Ni}, \mathrm{Cu}, \mathrm{Zn}, \mathrm{Pb}$, and $\mathrm{Hg}$ exceeded the background values of $9.82 \%, 47.80 \%, 13.72 \%$, and $76.06 \%$ in Guizhou Province, respectively. Therefore, it can be concluded that all these heavy metals tended to accumulate, but the average contents of all heavy metals did not exceed the limit of the national grade II soil environmental quality standard.
2. The analysis of results of principal components show that $\mathrm{Cd}$, As and $\mathrm{Hg}$ mainly come from natural sources and are influenced by geochemistry, with higher background values. $\mathrm{Pb}$ and $\mathrm{Zn}$ pollution is mainly because of mineral mining and smelting, waste residue accumulation, irrigation, and transportation. The enrichment of $\mathrm{Cr}$ and $\mathrm{Cu}$ may mainly come from dumped domestic waste, waste incineration from coastal residents, and unreasonable agricultural activities.

3. The geo-cumulation evaluation results showed that $I_{\mathrm{Pb}}>I_{\mathrm{Hg}}>I_{\mathrm{Cu}}>I_{\mathrm{Ni}}>I_{\mathrm{Zn}}>I_{\mathrm{Cr}}>I_{\mathrm{As}}>I_{\mathrm{Cd}}$. Among them, $\mathrm{Pb}$ was in no-to-moderate pollution, and $I_{g e o}$ of the rest of heavy metals was in clean level. $\mathrm{Pb}, \mathrm{Hg}$, and $\mathrm{Cu}$ pollution could be observed in some places. The results of the Nemerow comprehensive pollution index showed that As, $\mathrm{Cr}, \mathrm{Zn}$, and $\mathrm{Ni}$ were slightly polluted, while $\mathrm{Pb}, \mathrm{Hg}$, and $\mathrm{Cu}$ were moderately polluted. The calculation of the ecological hazard coefficient showed that the overall ecological risk was mild. The risk of $\mathrm{Hg}$ was moderate. At the same time, the potential ecological hazards of 8 heavy metals were ranked as $\mathrm{Hg}>\mathrm{Pb}>\mathrm{Cu}>\mathrm{Ni}>\mathrm{As}$ $>\mathrm{Cd}>\mathrm{Cr}>\mathrm{Zn}$ from strong to weak level.

4. At present, despite relatively low ecological hazards of the Wuma River Basin, the awareness of relevant departments are expected to be aroused for establishing and perfecting ecological protection measures in the mining areas of the Wuma River Basin, strengthening environmental protection training for coastal residents, properly solving the problems of random stacking of open-pit coal slag and pesticide residue pollution, and improving the centralized treatment system of coastal production and domestic waste. Only in this way, can the ecological environment of the Wuma River Basin develop in a more positive direction.

\section{ACKNOWLEDGEMENT}

This work was supported by The Key Project of Science and Technology Foundation, Guizhou Province (Qian Sci. Co. JZ, [2014], NO.2012), Guizhou Provincial Science-Technology Support Program, Guizhou Province (Qian Sci. Co.[2017], No.2580), and Technology Foundation, Guizhou Province (Qian Sci. Co., [2019], NO.1231).

\section{REFERENCES}

Aguiguri, M., Memetilson, E., Eniwal, M., Anival, M., Maituoheti, A. and Ma, G.F. 2017 . Heavy metal pollution and potential ecological risk of cultivated land in Oasis downstream of Kaidu river. J. Acta Entiae Circumstantiae., 37(6): 2331-2341.

Bao, S.D. 2007. Analysis of Soil Agrochemical. China Agricultural Press, Beijing. (in Chinese). 
Chen, Y.Y., Tang, M.Y, Wang, S.T., Wang, Q., Zhan W.X. and Huang G. 2016. Evaluation of heavy metal pollution in farmland soils in China based on Bibliometrics J. Chinese Soil Sci., 47(1): 219-225. (in Chinese).

Guo, C.H., Tu, W.J., Wang, P.C., Huang, B., Xiao, X.Y. and Xue, Q. H. 2017. Distribution characteristics and potential ecological risk assessment of heavy metals in farmland soils along rivers in typical lead-zinc mining areas. J. Agro-Environ. Sci., 36(10): 2029-2038. (in Chinese).

Hkanson, L. 1980. An ecological risk index for aquatic pollution control: A sedimentological approach. J. Water Res., 14(8):975-1001.

Hu, M. 2014. Distribution characteristics and pollution assessment of heavy metals in farmland soils of Dali county. J. Resour. Environ. Arid Areas, 28(1): 79-84.

Jin, X.Q., Wang, P., Guo, B.L., Guo, J. and Zhou, D.D.2017. Spatial distribution and pollution assessment of $\mathrm{Pb}, \mathrm{Zn}$, and $\mathrm{Cd}$ in small-scale farmland soils: A farmland along the Bijiang River in Yunnan province as an example .J. Chinese Environ. Eng., 11: 6190-6195. (in Chinese).

Li, Y.M., Ma, J.H., Liu, D.X., Sun, Y.L. and Chen, Y. F. 2015. Heavy metal pollution and potential ecological risk assessment of urban soil in Kaifeng. J. Environ. Sci., (3): 1037-1044. (in Chinese).

Lian, B. 2010. Microbial action in weathering and soil formation of carbonate rocks. J. Bull. Mineral. Petrol. Geochem., 29(1): 52-56.

Marrugo-Negrete, J., Pinedo-Hernández, J. and Díez, S. 2017. Assessment of heavy metal pollution, spatial distribution, and origin in agricultural soils along the Sinú River Basin, Colombia. J. Environ. Res., 154:380-388.

Massadeh, A., Alsharif, L., Dalaleh, R. and Hassan, M. 2006. Analysis of lead levels in local Jordanian and imported sheep meat and organs Using atomic absorption spectrometry. J. Environ. Monit. Assess., 115(1/2/3): 87-93.

Perveen, I., Raza, M.A., Sehar, S., Naz, I., Young, B. and Ahmed, S. 2017. Heavy metal contamination in water, soil, and milk of the industrial area adjacent to Swan River, Islamabad, Pakistan. J. Human Ecol. Risk Assess., (1)-22.

Wang, J., Zhang, Y.X. and Gao X. 2012. Research progress and prospects of heavy metals in urban surface dust. J. Geog. Res., 31(5): 821-830. (in Chinese).
Wang, Y.J., Liu, C., Zhou, D.M. and Chen, H.M. 2014. Objectively look at the present situation of soil environmental quality of cultivated land in China: Discussions and suggestions on relevant issues in the national bulletin of soil pollution investigation. J. Agro-Environ. Sci., 33 (8): 1465-1473. (in Chinese).

Wilding, L P. 1984. Spatial Variability: Its Documentation, Accommodation, and Implication to Soil Surveys. In Nielson, C. and Bouma, D.R. (eds.), Soil Spatial Variability. Proceedings of a Workshop of the ISSS and the SSSA., Las Vegas PUDOC, Wageningen, pp. 166-193.

Wu, X. L., Yang, Y. L., Xu, Q., Huang, Y.Y., Lu, G. H., He, J. and Liu, X. D.2011. Assessment of heavy metal pollution in surface soil of farmland along rivers and irrigation canals in Shenyang. J. Agro-Environ. Sci., 30(2): 282-288.

Yu, Y., Gao, H.C., Ma, J.H., Li, Y.X. and Kong, Y.H. 2013. Analysis and evaluation of heavy metals in the soil of Chaohe river basin in Miyun county. J. Environ. Sci., 34(9): 3572-3577.

Zang, X.H., Lu, Y.T., Yao, H., Zhang, S.C. and Jiang, X.X. 2016. Impact of urbanization on the distribution of heavy metals in soils of Shenfu new area and risk assessment. J. Agro- Environ. Sci., 35 (3): 471-477. (in Chinese).

Zeng, X.B., Su, S.M. and Ma, S.M. 2010. Heavy metal cycling and regulation in farmland ecosystem. J. Chinese Appl. Ecolog., 21(9): 2418-2426. (in Chinese).

Zhan, Y.Z., Jiang, X., Chen, C.X., Gao, H.G., Jin, X.C., Li, C. and Zhao, Z. 2011. Spatial distribution characteristics and pollution assessment of heavy metals in sediments of southwestern Taihu Lake. J. Res.Environ. Sci., 24(4): 363-370. (in Chinese).

Zhang, Y. X., Wang, J., Qin, F.X. and Zhang, H. 2012. Identification and comparison of sources of heavy metals in road dust and soil in Guiyang. J. Acta Scientiae Circumstantiae., 32(1): 204-212.

Zhao, X., Huang, Y., Li, J., Chen, G., Song, L.H., Lu, K.D. and Ning, C. 2015. Content level, spatial distribution, source, and potential ecological risk assessment of heavy metals in the soil around large waste incineration plants. J. Ecol. Environ. Sci., 24(6): 1013-1021. (in Chinese).

Zhou, H.B., Jiao, Y.M., Shi, Z.T., Ming, Q. and He, L . 2008. Magnetometric analysis and heavy metal pollution assessment of farmland soil along the Bijiang river in Yunnan J. Agro-Environ. Sci., 27(4): 1586-1591. 